\title{
LITERATURE REVIEW Brain derived neurotrophic factor mediated learning, fear acquisition and extinction as targets for developing novel treatments for anxiety
}

\author{
Aprendizado, aquisição e extinção de medo mediados pelo \\ fator neurotrófico derivado do cérebro, como alvos para o \\ desenvolvimento de novos tratamentos para ansiedade \\ Karina Soares de Oliveira', Ana Gabriela Hounie',2, Carolina Cappi', Juliana Belo Diniz'
}

\section{Keywords \\ Brain-derived neurotrophic factor, fear, anxiety disorders, learning, psychological extinction.}

\section{Palavras-chave}

Fator neurotrófico derivado do cérebro, medo, transtornos de ansiedade, aprendizagem, extinção psicológica.

\begin{abstract}
Anxiety and obsessive-compulsive related disorders are highly prevalent and disabling disorders for which there are still treatment gaps to be explored. Fear is a core symptom of these disorders and its learning is highly dependent on the activity of the neurotrophin brain-derived neurotrophic factor (BDNF). Should BDNF-mediated fear learning be considered a target for the development of novel treatments for anxiety and obsessive-compulsive related disorders? We review the evidence that suggests that BDNF expression is necessary for the acquisition of conditioned fear, as well as for the recall of its extinction. We describe the findings related to fear learning and genetic/epigenetic manipulation of $B d n f$ expression in animals and BDNF allelic variants in humans. Later, we discuss how manipulation of BDNF levels represents a promising potential treatment target that may increase the benefits of therapies that extinguish previously conditioned fear.
\end{abstract}

\section{RESUMO}

Os transtornos da ansiedade e o transtorno obsessivo-compulsivo (TOC) e transtornos relacionados são altamente prevalentes e incapacitantes. Apesar disso, ainda existem lacunas a serem exploradas em relação ao tratamento desses transtornos. O medo é um sintoma central desses transtornos e sua aprendizagem é altamente dependente da atividade do fator neurotrófico derivado do cérebro (BDNF). Porém, será que a aprendizagem de medo mediada pelo BDNF deve ser considerada um alvo para o desenvolvimento de novos tratamentos para transtornos da ansiedade, TOC e transtornos relacionados? Revisamos as evidências que sugerem que a expressão de BDNF é necessária para a aquisição do medo condicionado, bem como para a evocação de sua extinção. Descrevemos os resultados relacionados a aprendizagem de medo, manipulação genética e epigenética da expressão de Bdnf em animais e variantes alélicas de BDNF em seres humanos. Posteriormente, discutimos como a manipulação dos níveis de BDNF representa um alvo em potencial para o tratamento, o que pode aumentar os benefícios das terapias que extinguem o medo previamente condicionado.

1 University of São Paulo Medical School, Hospital das Clínicas, Institute of Psychiatry (IPq-HCFMUSP), OCD Research Program. 2 Federal University of São Paulo (Unifesp), Department of Psychiatry and Psychology, Child and Adolescent Psychiatry Unit (UPIA).

Received in

5/15/2016

Approved in

$7 / 25 / 2016$

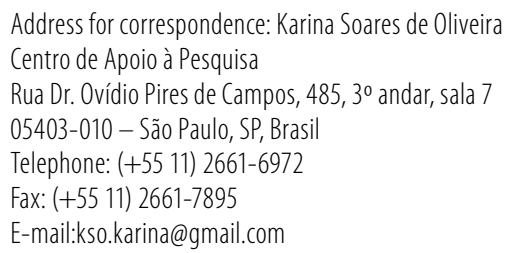




\section{INTRODUCTION}

Anxiety disorders, such as generalized anxiety disorder (GAD), social phobia (SoPh), post-traumatic stress disorder (PTSD), panic disorder (PD), and obsessive-compulsive and related disorders (OCRD), are amongst the most prevalent mental disorders worldwide and are frequently associated with high disability and impaired quality-of-life ${ }^{1,2}$. Pharmacotherapy with anxiolytics or antidepressants and disorder-oriented psychotherapy are the best evidence-based treatments for most anxiety disorders and OCRD ${ }^{3}$. However, these interventions have not yet been able to overcome much of the burden related to these disorders. Treatment interventions usually require long-term maintenance, and may not be suitable or available for a significant proportion of patients $\mathrm{s}^{4,5}$. These unmet needs regarding anxiety and OCRD make the investigation of new treatment targets necessary. Since fear and anxiety are the core symptoms of most anxiety and OCRD, it is likely that new targets are located at the systems that control these emotional manifestations ${ }^{6}$.

Fear and anxiety encompass similar physiological responses - tachycardia, hyperventilation, increased sweating, and tremor - and cognitive experiences repetitive thoughts about putative threatening situations or disasters. However, these concepts differ regarding their temporal relationship with threat: while fear represents the immediate response to current threat and fight-or-flight reactions, anxiety is related to the process of anticipation of future threat and avoidance ${ }^{7,8}$. Learning what to fear and what not to fear or avoid is a dynamic process that occurs along the lifespan and that is highly adaptive to different environments. Nonetheless, fear and anxiety can be displaced or exaggerated, as in the case of anxiety disorders and OCDR; thus anxiety disorders and OCDR are being hypothesized as disorders of fear learning.

One of the possible ways by which we learn that a stimulus is menacing is through fear conditioning? ${ }^{9}$. Fear conditioning requires a neutral stimulus (e.g. light, sound, or location) to be repeatedly presented preceding an aversive unconditioned stimulus (US) (e.g. shock, sudden loud sound, painful stimulus). Through classic conditioning, the initially neutral stimulus acquires the ability to trigger the fear response, becoming a conditioned stimulus (CS) with properties that resemble those of the US ${ }^{10}$. Once the fear response is learned, it can be extinguished by the repeated presentation of the CS not followed by the US ${ }^{11}$. The concepts of fear conditioning and extinction are represented in Figure 1.

The extinction of fear responses is the main concept that underlies many psychotherapeutic protocols specifically developed for the treatment of anxiety and OCRD, e.g. exposure and response prevention for OCD ${ }^{12,13}$, social exposure for SoPh ${ }^{14}$ and prolonged exposure for PTSD ${ }^{15}$. The behavioral framework that underlies the use of exposure therapy for anxiety disorders is represented in Figure 2. According to this framework, individuals with resistance to extinction or who do not retrieve the previously learned extinction should be more prone to develop anxiety and resistance to treatment ${ }^{16}$

Fear learning requires memorization processes such as activity-dependent long-term potentiation (LTP) ${ }^{17}$. Together with other neurotrophins, brain-derived neurotrophic factor (BDNF) is a protein that regulates activity-dependent neuronal modifications and promotes neuronal proliferation, differentiation, survival and death during central nervous system (CNS) development ${ }^{18}$.

BDNF synthesis occurs from a precursor form, the proBDNF. After transcription in the endoplasmic reticulum, pro-BDNF is packaged into secretory vesicles by Golgi apparatus. Through the action of proteases, most of them in extracelular space, prodomain is cleaved from pro-BDNF, releasing mature domains. In response to extracellular and intracellular signals, BDNF secretion occurs at both pre- and postsynaptic sites. BDNF is released into different pathways that can be either constitutive or regulated (that secretes BDNF in response to neuronal activity) ${ }^{19}$.

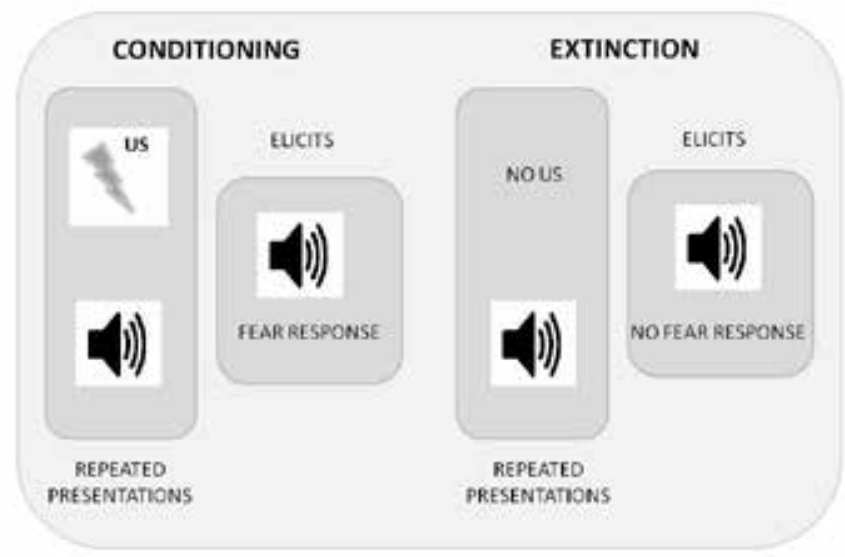

Figure 1. Schematic representation of the fear conditioning phenomena. US: unconditioned stimuli.

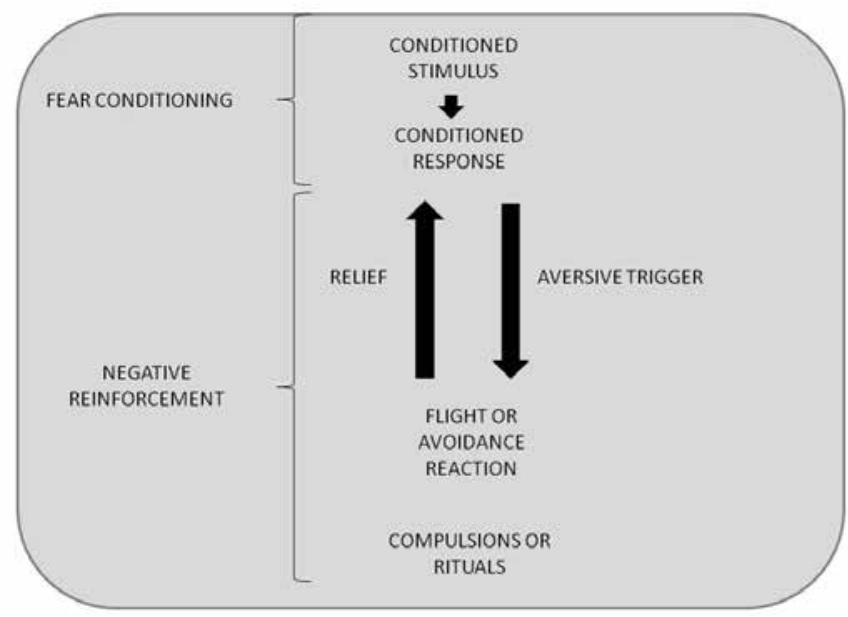

Figure 2. Schematic representation of the putative maintenance mechanism of conditioned fear responses. 
BDNF actions occurs by binding and activating the tropomycin receptor kinase B or TrkB. BDNF binds to TrkB receptors located on presynaptic and postsynaptic sites, leading to the activation of signal transduction pathways, including mitogen activated protein kinase/extracellular signal-regulated protein kinase (MAPK/ERK), phospholipase $C_{Y}(P L C Y)$, and phosphoinositide 3-kinase (PI3K) pathways ${ }^{20}$. Activation of BDNF/TrkB signaling causes phosphorylation of other receptors (e.g. glutamate receptors, AMPA and NMDA), increase in neurotransmitter release from presynaptic sites, enhancement of protein synthesis, axon growth, and neuronal differentiation, proliferation and survival21.

Several studies have demonstrated that BDNF plays a role in regulating neural structure and function by participating in short-term synaptic plasticity and early and late LTP22. Such processes are of fundamental importance for learning and memory consolidation ${ }^{23}$, which are, in turn, responsible for the long-term effects of environmental stimuli, such as stressful life events. For its participation in LTP processes during fear learning, BDNF has been hypothesized as a possible target for the development of interventions that may improve fear extinction.

Our aim was to review the current literature and to understand how interventions that directly or indirectly interfere with BDNF levels became potential treatments for anxiety and OCRD and how we should guide future research.

\section{METHODS}

To prepare for this manuscript, a literature search was performed in July 2015 using the PubMed and Embase databases for articles that contained the terms "brain-derived neurotrophic factor", AND "learning" AND "fear" as words from the title or abstract, no limit for date of publication was specified. In total, the initial search resulted in 87 articles. Two researchers independently examined the list of abstracts and excluded articles for which access to full-text (abstracts published in annals of congresses) was not available or in which an experiment that directly evaluated BDNF genetic variants, BDNF plasma/serum levels or expression was absent. The reference lists from the 71 remaining articles and reviews were checked for additional original articles on the subject. Thirteen articles were classified as reviews and presented no original data. Two article presented original data concerning BDNF manipulation, but did not assess any direct or indirect measure of fear and one study investigated the effects of BDNF on appetitive learning. The articles retrieved in the search that evaluated BDNF mediated fear learning directly are described in the text. Additional studies retrieved in the search but not directly related to the subject are briefly described in Table 1 .

Table 1. Additional studies that evaluated BDNF-related mechanisms of fear learning

\begin{tabular}{|c|c|c|}
\hline Author (year) & Subjects & Main findings \\
\hline Song et al. $(2015)^{51}$ & Animals (Mice) & $\begin{array}{l}\text { Genetic deletion of } \mathrm{Ca} 2+/ \text { calmodulin-dependent protein kinase IV impaired contextual fear memory and learning in temporal } \\
\text { dissociative passive avoidance task without affecting BDNF transcription }\end{array}$ \\
\hline Gururajan et al. $(2015)^{52}$ & Animals (Rats) & $\begin{array}{l}\text { Heterozygous BDNF knockout rats (but not wild type animals) treated with corticosterone presented significant impairment in } \\
\text { extinction learning }\end{array}$ \\
\hline Wang et al. $(2015)^{53}$ & Animals (Mice) & High-fat diet compared to a regular-fat diet impaired spatial memory aging effects and reduced BDNF levels \\
\hline Gibbons et al. $(2014)^{54}$ & Animals (Mice) & $\begin{array}{l}\text { Running wheel increased BDNF expression in dentate gyrus and improved performance in aged mice, while diet containing } \\
\text { epigallocatechin-3-gallate and } \beta \text {-alanine had no age-related effect }\end{array}$ \\
\hline Dincheva et al. $(2014)^{55}$ & Animals (Mice) & $\begin{array}{l}\text { In Met allele carriers, contextual fear expression during adolescence is not altered compared to wild type, but in adulthood their } \\
\text { performance is worst then wild type }\end{array}$ \\
\hline Chen et al. $(2015)^{56}$ & Animals (Rats) & $\begin{array}{l}\text { Sevoflurane administration during stress reduced the level of BDNF in the hippocampus, while administration after increased } \\
\text { BDNF levels compared with the control group }\end{array}$ \\
\hline Fan et al. $(2016)^{57}$ & Animals (Mice) & Enriched environment attenuated surgery-induced learning deficits mediated by BDNF expression \\
\hline Heldt et al. $(2014)^{58}$ & Animals (Mice) & Appetitive learning (not only fear/aversive learning) is impaired in mice with decreased BDNF expression in the amygdala \\
\hline Schulz-Klaus et al. $(2013)^{59}$ & Animals (Rats) & Expression of BDNF protein in the perirhinal cortex is increased after fear conditioning and is essential for learning effects \\
\hline Psotta et al. $(2013)^{60}$ & Animals (Mice) & $\begin{array}{l}\text { Heterozygous BDNF knockout mice, showed similar age-dependent decrease in BDNF levels in brain areas essential for fear } \\
\text { extinction and worse fear extinction learning deficits compared to wild type animals }\end{array}$ \\
\hline Endres and Lessmann $(2012)^{61}$ & Animals (Mice) & Compared to wild type animals, heterozygous BDNF knockout mice \\
\hline Choi et al. $(2012)^{62}$ & Animals (Mice) & $\begin{array}{l}\text { TrkB antagonism and viral-mediated BDNF deletion within the prelimbic areas results in decreased of appetitive and aversive } \\
\text { emotional learning }\end{array}$ \\
\hline Meis et al. $(2012)^{63}$ & Animals (Mice) & $\begin{array}{l}\text { Heterozygous BDNF knockout mice presented intact cortico-amygdala pathway long-term potentiation, while in the thalamo- } \\
\text { amygdala pathway was abolished. Postsynaptic inhibition of TrkB receptors blocked long-term potentiation in the thalamic } \\
\text { pathway }\end{array}$ \\
\hline Uutela et al. $(2012)^{64}$ & Animals (Mice) & $\begin{array}{l}\text { Fmr1 knockout mice, an animal model of Fragile X Syndrome, showed declined age-related BDNF levels in the hippocampus and } \\
\text { impairment of contextual fear learning }\end{array}$ \\
\hline Kleschevnikov et al. $(2012)^{65}$ & Animals (Mice) & $\begin{array}{l}\text { Treatment with two different GABAB receptor antagonists increased hippocampal levels of BDNF and restored memory of novel } \\
\text { place recognition in a genetic model of Down syndrome }\end{array}$ \\
\hline
\end{tabular}




\begin{tabular}{|c|c|c|}
\hline Author (year) & Subjects & Main findings \\
\hline Oyagi et al. $(2011)^{66}$ & Animals (Mice) & $\begin{array}{l}\text { BDNF levels were increased in the cortex, striatum and olfactory bulb of knock-out mice for the heparin-binding epidermal growth } \\
\text { factor-like growth factor gene. These knock-out mice showed impairments in spatial memory and fear learning }\end{array}$ \\
\hline Kimura et al. $(2010)^{67}$ & Animals (Mice) & $\begin{array}{l}\text { Both BDNF and TkrB levels were reduced in the hippocampus of heterozygous } \beta \text {-Site amyloid precursor protein cleaving enzyme } 1 \\
\text { gene knock-out mice, which is an animal model for Alzheimer's disease }\end{array}$ \\
\hline Jin et al. $(2009)^{68}$ & Animals (Mice) & $\begin{array}{l}\text { By modulating BDNF and the expression of other factors, fustin flavonoid attenuated amyloid-beta peptide-induced impaired } \\
\text { learning }\end{array}$ \\
\hline Rossato et al. $(2009)^{69}$ & $\begin{array}{l}\text { Animals } \\
\text { (Rats) }\end{array}$ & $\begin{array}{l}\text { BDNF expression mediated the effect of dopamine receptor manipulation (in the ventral tegmental area of the hippocampus) on } \\
\text { long-term memory persistence }\end{array}$ \\
\hline Woolley et al. $(2009)^{70}$ & Animals (Rats) & $\begin{array}{l}\text { Subchronic administration of an AMPA receptor positive modulator elevated BDNF mRNA expression in the dorsal hippocampus, } \\
\text { CA1 hippocampal region and vmPFC. Acute administration of the same substance attenuated a scopolamine-induced impairment } \\
\text { of cued fear conditioning }\end{array}$ \\
\hline Bilbo et al. $(2008)^{71}$ & Animals (Rats) & $\begin{array}{l}\text { Neonatal infection with } E \text {. coli led to decreased BDNF mRNA induction in all hippocampal regions accompanied by a large increase } \\
\text { in interleukin-1b mRNA in CA1 hippocampal region }\end{array}$ \\
\hline Greenwood et al. $(2009)^{72}$ & Animals (Rats) & $\begin{array}{l}\text { Six weeks of wheel running increased mRNA in the dentate gyrus, CA1, and the basolateral amygdala. This increase was } \\
\text { accompanied by improved contextual fear learning. No effect of wheel running training was observed on fear extinction }\end{array}$ \\
\hline Gourley et al. $(2009)^{73}$ & Animals (Rats) & A marked decrease in BDNF gene expression in the orbitofrontal cortex was observed following corticosterone exposure \\
\hline Liu et al. $(2008)^{74}$ & Animals (Mice) & $\begin{array}{l}\text { Treadmill exercise training transiently increased the BDNF expression in the hippocampus and persistently increased hippocampal } \\
\text { levels of TrkB and phosphorylated TrkB. These alterations were positively correlated with passive avoidance performance }\end{array}$ \\
\hline Bozdagi et al. $(2008)^{75}$ & Animals (Mice) & VGF-derived peptide TLQP62 induced potentiation of CA1 field EPSPs through BDNF-dependent mechanism \\
\hline Chen et al. $(2007)^{76}$ & Animals (Rats) & $\begin{array}{l}\text { An NMDA receptor antagonist blocked the increase in the number of BDNF immune reactive hippocampal neurons following fear } \\
\text { conditioning and impaired contextual fear learning }\end{array}$ \\
\hline Ou et al. $(2007)^{77}$ & Animals (Rats) & $\begin{array}{l}\text { Administration of actinomycin D or anisomycin blocked fear conditioning and inhibited a conditioning-induced increase in BDNF. } \\
\text { Inhibitors for N-methyl-D-aspartate (NMDA) receptor, L-type voltage-dependent calcium channel (L-VDCC), adenylyl cyclase, } \\
\text { CAMP-dependent protein kinase (PKA), and calcium/calmodulin-dependent kinase IV (CaMKIV) significantly reduced the increase }\end{array}$ \\
\hline Jones et al. $(2007)^{78}$ & Animals (Mice) & $\begin{array}{l}\text { Mice exposed to trials of unpaired or paired odours and footshocks, showed increased BDNF mRNA expression in the olfactory } \\
\text { bulb and anterior piriform cortex when stimuli were unpaired and additionally in the posterior piriform cortex and basolateral } \\
\text { amygdala when stimuli were paired }\end{array}$ \\
\hline Moretti et al. $(2006)^{79}$ & Animals (Mice) & BDNF expression remained unaltered in an animal model of Rett Syndrome that presents memory and learning deficits \\
\hline Aguilar-Valles et al. $(2005)^{80}$ & Animals (Rats) & $\begin{array}{l}\text { Increased BDNF gene expression was observed in the hippocampus in response to stress produced by the Morris water-maze } \\
\text { paradigm }\end{array}$ \\
\hline Alonso et al. $(2005)^{81}$ & Animals (Rats) & $\begin{array}{l}\text { BDNF expression in the parietal cortex was shown to be essential for both short-term memory and long-term memory formation } \\
\text { of inhibitory avoidance learning }\end{array}$ \\
\hline Chourbaji et al. $(2004)^{82}$ & Animals (Mice) & $\begin{array}{l}\text { Mice with a } 60 \% \text { reduction in BDNF expression due to heterozygous gene disruption showed unchanged levels of monoamines, } \\
\text { together with normal performance in behavioural tests that investigated anxiety and fear-associated learning. In these mice, } \\
\text { choline acetyltransferase activity was significantly reduced in the hippocampus }\end{array}$ \\
\hline Barrientos et al. $(2004)^{83}$ & Animals (Rats) & $\begin{array}{l}\text { Intrahippocampal injection of interleukin } 1 \mathrm{~b} \text { impaired contextual fear learning through reduction or blockage of increases of BDNF } \\
\text { expression in that region }\end{array}$ \\
\hline Barrientos et al. $(2003)^{84}$ & Animals (Rats) & $\begin{array}{l}\text { Intrahippocampal injection of the interleukin } 1 \mathrm{~b} \text { receptor antagonist prevented both the BDNF down regulation and the memory } \\
\text { impairments produced by social isolation }\end{array}$ \\
\hline Gorski et al. $(2003)^{85}$ & Animals (Mice) & $\begin{array}{l}\text { Early-onset forebrain-restricted BDNF mutant mice showed impaired learning in the Morris Water Maze. The mice did not present } \\
\text { altered sensory processing and gating, measured by the acoustic startle response, nor did they show any alterations in basal } \\
\text { anxiety measurements }\end{array}$ \\
\hline
\end{tabular}

\section{RESULTS}

So far, animal studies comprise the majority of research on BDNF and fear conditioning. Since BDNF expression was consistently proven to change according to learning paradigms ${ }^{24}$, several methods have been applied to manipulate BDNF levels and its effects. In the last decades, knockout animals carrying a defective allele of the Bdnf gene, exposure to environmental factors that are known to alter BDNF expression, the investigation of functional Bdnf allelic variants and the use of BDNF agonists have led to consistent replication of results regarding effects of BDNF on fear acquisition and extinction.

Below, we summarize the main results regarding fear learning and BDNF according to different experimental procedures. Experiments of fear learning in rodents vary widely. While some experiments directly investigate fear conditioning and extinction through pairing of neutral and aversive stimulus, others investigate spatial learning and working memory through fear-related learning tasks such as the acquired ability to find the easiest way out of a trap (e.g.: Morris water maze). In addition, the fear conditioning 
experiments may also vary regarding the type of CS. Some experiments use cues while others use context (a specific location). The neuronal pathway activated during these different types of learning experiments is not identical; therefore, small experimental variations may lead to divergent results. In addition, the complexity of multi-level molecular regulation of BDNF is not completely understood. Small variations in the methodology applied to interfere with BDNF transcription may also result in divergent findings.

\section{Bdnf and fear learning}

\section{Hippocampus}

Liu et al. tested the fear conditioning characteristics of $B d n f$ heterozygous knock-out mice and demonstrated that contextual fear learning (i.e., when a location functions as CS) but not cued fear learning (tone footshock pairing) was impaired compared to controls. In a second experiment, infusion of the recombinant Bdnf protein into the hippocampal formation was able to revert the impairment in contextual learning ${ }^{25}$. These authors did not investigate extinction retention of the fear response in Bdnf heterozygous mice.

Heldt et al. ${ }^{26}$, on the other hand, injected a lentivirus expressing Cre-recombinase to promote the site-specific deletion of $B d n f$ in the dorsal hippocampus of adult mice. The hippocampal deletion of $B d n f$ led to impairment in object recognition, spatial learning (as demonstrated with the Morris water maze) and extinction of conditioned fear with an auditory cue (demonstrated by higher fear-potentiated startle and freezing in the end of the extinction session), although no effects were observed in the acquisition or expression of fear response. Differently from Liu et al.'s study, Heldt et al. did not evaluate the effects of contextual fear learning. In addition, when deleting Bdnf from the hipoccampus of adult mice, Heldt et al. aimed to evaluate the acute effects of hipoccampal Bdnf loss and differentiate those effects from the developmental effects of general lower Bdnf levels that are inherent to experiments with Bdnf heterozygous knock-out mice.

When comparing mutant mice with a selective disruption of activity-dependent Bdnf expression to not genetically manipulated mice, Sakata et al. ${ }^{27}$ showed that mutant mice are more prone to behavioral perseveration, including perseveration of conditioned fear responses due to impairment in extinction retention. Those animals exhibited selective impairment of Bdnf-dependent but not Bdnf-independent late LTP in the hippocampus.

In summary, constitutive lower levels of Bdnf were associated with impaired contextual fear learning and this effect was reverted by injecting Bdnf in the hipoccampus. Acute Bdnfblocking (regulated pathway) in the hippocampus was associated with impaire dextinction of cued fear learning.
Similarly, extinction of cued fear learning was disrupted in animals with a mutation that specifically reduced acitivitydependent (but not constitutive) Bdnf expression. These same animals have been proven to show impaired late LTP in the hipoccampus. In different experiments, the constitutive effects of Bdnf in the hippocampus have been associated with learning deficits during contextual fear conditioning while activity-dependent and acute Bdnf effects have been associated with deficits of cued fear extinction.

\section{Amygdala}

Methods of manipulation of the Bdnf receptor known as TrkB allow the investigation of localized interruption of Bdnf signaling and the isolation of Bdnf effects on the amygdala. Chhatwal et al..$^{28}$ investigated the effect of Bdnf in the formation of extinction memory manipulating TrkB in the basolateral nucleus of the amygdala (BLA) through a viral gene-delivery system. Infected neurons express a truncated and inactive form of the TrkB receptor (TrkB.t1). Rats expressing TrkB.t1 in the BLA were unable to consolidate memory of the extinction training despite showing similar fear extinction compared to controls.

Rattiner et al. ${ }^{29}$ used both the viral gene-delivery system of TrkB.t1 and a TrkB receptor blockade to examine the role of TrkB on amygdala-dependent learning and memory. With the inhibition of TrkB in the amygdala by either methods, rats became unsusceptible to acquisition and memory of fear conditioning although the expression of fear was not impaired. The association between effects of Bdnf on the amygdala and fear extinction was not tested.

Similarly, administration of the TrkB ligand scavenger, TrkB IgG and a Trk-specific tyrosine kinase inhibitor in the amygdala of rats impaired fear memory ${ }^{30}$. Differently from the effects of blocking Bdnf acute action in the hippocampus, interference with the action of Bdnf in the amygdala inhibits the acquisition and consolidation of cued conditioned fear ${ }^{29}$.

When extinction takes place, a new memory is formed and it competes with the preceding memory of acquisition, during recall. Previous studies - that were not among the articles retrieved in the search for this review for not being related to BDNF/Bdnf activity - had already described that the mechanism of extinction retention is dependent on the activation of the ventromedial prefrontal cortex (VmPFC) during memory recall of extinction both in rodents ${ }^{31}$ and humans ${ }^{32}$. The VmPFC of the human brain is homologue to the infralimbic cortex of the rodent brain. The abbreviation VMPFC will be used to refer to both species. The vmPFC is responsible for maintaining extinction during recall but depends on the activation of the hippocampus ${ }^{32}$. Blocking Bdnf in the hippocampus, during extinction, may interfere with the activation of the VmPFC during recall resulting in loss of the extinction learning. The schematic representation of these hypotheses is represented in Figure 3. 


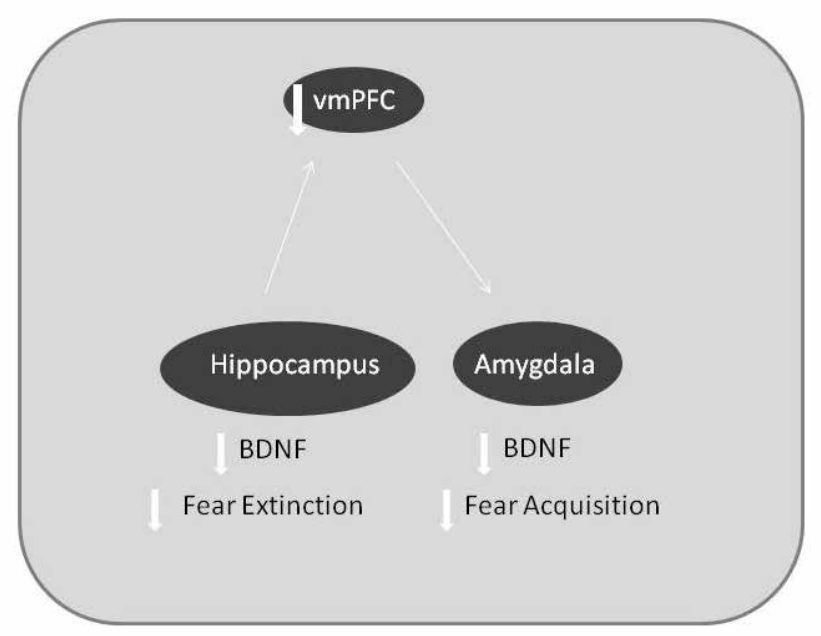

Figure 3. Schematic representation of the brain regions related to fear conditioning and extinction. vmPFC: ventromedial pre-frontal cortex; BDNF: brain-derived neurotrophic factor.

\section{Manipulation of differential Bdnf expression and epigenetic mechanisms}

The Bdnf gene has multiple Bdnf mRNA transcripts that code the same protein, which suggests multilevel regulation of its expression. Despite coding the same protein, specific transcript isoforms can regulate trafficking and targeting of the mRNA. In addition to transcript isoforms, epigenetic mechanisms such as histone acetylation and DNA methylation may contribute to ongoing regulation of Bdnf in the CNS. The following articles describe how the interference with regulatory mechanisms can impact memory consolidation of fear acquisition and extinction. Such findings are of interest because they show how the use of substances or activities that interfere with epigenetic mechanisms may impact fear acquisition and extinction without any direct manipulation of BDNF/Bdnf protein of BDNF/Bdnf DNA coding.

\section{Bdnf transcripts}

Rattiner et al. ${ }^{33}$ studied the expression of Bdnf multiple transcripts: 5'-exons (I-IV) and 3'-exon (V). Rats were submitted to light-shock pairings for conditioning fear and killed 2 hours afterwards. Analysis of their amygdala demonstrated an increase in transcripts containing exons I, III and V, while the amount of transcripts containing exons II and IV was similar to that verified in controls not submitted to the fear conditioning paradigm. This suggests that behavioral changes may be the result of differential regulation of $B d n f$ promoters $^{33}$.

Barnes and Thomas ${ }^{34}$ have shown that hippocampal injection of an inhibitor of proteolysis of the proBdnf protein precludes the acquisition and extinction of contextual fear memory. Additional evidence of differential expression of Bdnf promoters include findings from McDowell et al. ${ }^{35}$ that found that knockout mice for the transcriptional factor known as Calcium-Response Factor expressed exclusively the exon IV and presented reduced total levels of $\mathrm{Bdn} \mathrm{f}^{35}$; and from Preethi et al.$^{36}$ who demonstrated that rats treated with Bacopa monniera (a medicinal Ayurvedic herb known as a neural tonic and memory enhancer) showed up-regulated Bdnf exon IV transcripts in the hippocampus and improved contextual fear memory consolidation.

\section{Histone acetylation}

Several studies evaluated the relationship of fear learning with epigenetic mechanisms that interfere with differential Bdnf expression. Bredy et al. ${ }^{37}$ have shown that fear conditioning is regularly followed by increases in histones $\mathrm{H} 3$ and $\mathrm{H} 4$ acetylation around the $\mathrm{P} 1$ and $\mathrm{P} 4$ promoters of $B d n f$, respectively. In addition, the extinction procedure was followed by an increase in exons I and IV of Bdnf mRNA. Using valproic acid (VPA), a histone deacetylase inhibitor, the authors evaluated the effects on Bdnf expression following behavioral training. Compared with controls that were injected with valpromide, an analogue of VPA that shares its anticonvulsant and mood stabilizing effects but is not a histone deacetylase inhibitor, mice that were injected with VPA prior to training showed enhanced and dosedependent long-term memory for extinction. Furthermore, an increase in acetylation following extinction was observed only in histone $\mathrm{H} 4$, around P1 and P4 Bdnf promoters. Only transcripts containing exon IV were elevated. These findings suggest an association between histone $\mathrm{H} 4$ acetylation and the extinction of conditioned fear ${ }^{37}$.

\section{DNA methylation}

Lubin et al. ${ }^{38}$ demonstrated that regulation of $B d n f$ through epigenetic mechanisms also occurs during contextual fear memory consolidation. The authors observed an increase in exon IV containing transcripts in the hippocampus and active demethylation of exon IV following fear conditioning. To evaluate how much decreased DNA methylation alters Bdnf transcription, the effect of DNA methyltransferases (DNMT), which regulates de novo or maintenance of methylation at CpG island sites within DNA was examined. Memory consolidation was assessed 24 hours after DNMT inhibition and less freezing was observed in the experimental group, suggesting that regulation of DNA methylation is necessary for memory consolidation ${ }^{38}$.

\section{Confirmatory findings for histone acetylation and DNA methylation}

Following the same line of research, Sui et al. ${ }^{39}$ demonstrated that rats that received stimulation of the VMPFC have increased levels of total DNMT, total histone acetyltransferases, and global acetylated histones $\mathrm{H} 3$ and $\mathrm{H} 4$ following stimulation. 
The use of inhibitors of the enzymes that control methylation/demethylation precluded demethylation and acetylation of the Bdnf and the process of LTP39.

In summary, differential exon usage in the hippocampus relates to transcriptional control of $B d n f$. Prior findings in the amygdala suggest that site-specific initiation of transcription of Bdnf might be used to signal salient features of environmental cues. In addition, the multiple Bdnf mRNA transcripts have been shown to be sensitive to epigenetic modification through histone acetylation and DNA methylation. These epigenetic mechanisms are, in turn, dynamically involved in memory consolidation.

Taken together, these results highlight that transcription regulation varies according to environmental conditions and that histone acetylation and DNA methylation can be potent transcription control mechanisms even in non-dividing cells. The significance of $B d n f$ differential regulation is, however, not completely understood. It could be that the only function of differential exon usage is for differential transcriptional control. Notwithstanding, it is still possible that differential regulation relates to function.

As well, processes that increase or reduce acetylation and methylation might impact memory consolidation of fear acquisition or extinction if they take place during the learning phase. In the future, a better understanding of those processes might provide clues about interventions that have the potential to reduce the consolidation of fear memories or to promote the consolidation of extinction memories.

\section{Bdnf genetic variants in humans}

Some BDNF allelic variants have been shown to interfere with gene expression ${ }^{40}$. There are two main functional variants ${ }^{41}$ : the BDNF-linked complex polymorphic region (LCPR-BDNF), a microsatellite polymorphism associated with lower transcription levels of the protein; and the val66met that refers to the substitution of valine for methionine at one prodomain of the BDNF protein. Heterozygotes (Metcarriers) for the val66met variation affect approximately 20 to $30 \%$ of the Caucasian population, while homozygotes (MetMet-carriers) affect only 2 to $3 \%{ }^{42}$.

Hajcak et al. ${ }^{43}$ described that the Val66Met genotype is associated with impaired fear conditioning in healthy humans. Fear was conditioned by pairing rectangles of different sizes with a mild shock. Met-carriers showed a deficit in the startle response to the rectangle that was paired with the shock ${ }^{43}$. In another study with different methodology, Met-carriers also showed a behavioral deficit in fear conditioning. Pictures of male faces were used as stimuli and fear learning was quantified by skin conductance responses (SCR) and fear potentiated startle (FPS). Learning deficits were indicated by an absence of FPS responses during stimuli presentation after conditioning ${ }^{44}$. Later, the same group ${ }^{45}$ replicated this finding and evaluated the fear response pattern of neural activation by functional MRI. As in the former study, Met-carriers showed deficits in fear conditioning. In addition, Met-carriers had heightened amygdala activation during conditioning according to functional neuroimaging. The authors then suggested that the Val66Met genotype could have a protective effect on the development of anxiety disorders mediated by reduced synaptic plasticity induced by negative experience ${ }^{44}$.

Another recent study on BDNF val66met polymorphism in humans, showed that Met-carriers are more likely to generalize context-dependent fear responses to novel (otherwise safe) contexts ${ }^{46}$. The interpretation of these findings was the opposite of the studies described earlier: that Met-carriers are more (not less) vulnerable to develop anxiety disorders.

A study conducted both in mice and in humans also investigated the effects of the presence of Bdnf/BDNF val66met SNP in fear conditioning. In both Met-carrier knock-in mice and human Met-carriers, the behavioral response during fear conditioning was not significantly different from the respective control groups. However, both showed impairments in the process of extinction of the conditioned fear response according to measurements of freezing behavior in mice and the variation in skin conductance in humans. Low levels of c-Fos (a protooncogene of Fos family of transcription factors) were verified in the vmPFC of Met-carrier mice. In human Met-carriers, a decrease in activation of the vmPFC was observed compared with non-Met-carriers, according to data from $\mathrm{FMR}^{47}$.

These apparently contradictory findings regarding the val66met genotype in humans point toward the complexity of the interaction between BDNF mediated learning mechanisms and the consolidation of fear memories. It is not as simple as looking for the genetic variant that predisposes to anxiety through enhancement of fear learning or the one that is protective by increasing consolidation of extinction memories. When evaluating allelic variations, we have some background information about constitutive pathways involving BDNF but we still ignore much of allelic variations impact on regulatory pathways that may use redundant mechanisms not BDNF-dependent. Therefore, the effects of BDNF allelic variations have to be considered under dynamic and multifactorial conditions.

\section{Bdnf/BDNF agonists}

The use of Bdnf receptor agonists was shown to relieve animals from fear learning deficits possibly related to diminished Bdnf expression. Zeng et al. ${ }^{48}$ have shown that chronic treatment with a Bdnf receptor agonist improves both contextual and cued fear-related learning in aged rats. Andero et al..$^{49}$ found that activation of amygdala Bdnf receptors by systemic administration of a Bdnf receptor 
agonist enhanced fear conditioning and extinction learning and rescued mice with a history of immobilization stress from fear extinction deficits. Based on these results, some researchers raised the hypothesis that using BDNF agonists could restore fear extinction in patients who cannot recall extinction learning following traumatic experiences. The use of BDNF itself in humans was investigated in previous trials, but initial results proved negative, possibly due to its plasma instability $^{50}$. Therefore, the use of BDNF agonists instead of BDNF itself is a promising alternative. Notwithstanding, so far, there is no information from clinical trials to support this hypothesis.

Additional studies that indirectly evaluated the relationship between BDNF and fear learning are described briefly in Table 1.

\section{DISCUSSION}

The recent literature provides a complex picture of how BDNF expression interferes with acquisition and extinction of conditioned fear. There are several pathways that share, as a common end point, alterations in BDNF expression or differential splicing, suggesting that several mechanisms may interfere with fear memory acquisition and extinction through BDNF. Hence, to understand the impact of alterations of BDNF on fear and anxiety, we have to consider BDNF as part of a chain of multiple dynamically interacting variables that determine the likelihood of maintaining or extinguishing a fear memory ${ }^{86}$.

The effects ofBDNF on fear memoryand its repercussions are not straightforward. Increased BDNF expression can reinforce the consolidation of both fear acquisition and fear extinction with opposite consequences. Scientists disagree regarding the effect, for example, of the val66met BDNF polymorphism on vulnerability for anxiety disorders. While some believe that the Met-carrier genotype can be protective ${ }^{44,45}$, others believe the same genotype increases the likelihood of anxiety disorders ${ }^{46,47}$. Those who advocate for the protective role of the Met-carrier genotype consider its effects on conditioned fear while those who believe in its prejudicial effect are based on its role over fear extinction.

In humans, further research is necessary to confirm the preliminary findings of the prejudicial effect of the Metcarrier genotype for the val66met BDNF polymorphism on cognitive-behavior psychotherapy for PTSD ${ }^{87}$. It is still unclear if patients carrying such mutation would require additional interventions to improve extinction due to an intrinsic resistance to exposure treatment. Other genetic variants and environment manipulations may interfere with extinction but the information is still scarce for human subjects.
The broad participation of BDNF in processes related to fear acquisition and extinction makes it a reasonable target for new anxiety treatments. The use of BDNF agonists is currently under investigation at the pre-clinical level. Should the use of agonists prove useful, the greatest challenge will be determining under what circumstances the use of BDNF improves fear extinction.

Beyond BDNF agonists, other interventions have the potential to alter BDNF expression indirectly. Physical exercise, for example, increases BDNF expression in the hippocampus, which is critically involved in memory processes ${ }^{88,89}$. Augmentation of the effects of exposure therapy with physical exercise has been tested in PTSD patients with promising results ${ }^{90}$. Longer and bigger trials are still necessary to confirm these initial positive findings.

Of note, the use of antidepressants also increases BDNF expression and the activation of its receptor TrkB in animal models ${ }^{91,92}$. The effect of antidepressants as enhancers of fear extinction, however, is still matter of debate. Some animal studies found facilitated extinction or extinction retention with chronic use of antidepressants ${ }^{93-95}$ albeit it has not been always replicated ${ }^{96}$ perhaps due to sex-related differences ${ }^{97}$. One small human study found that chronic use of antidepressants may enhance extinction although it is not clear that the BDNF pathway is the one responsible for such effects ${ }^{98}$.

\section{CONCLUSION}

In summary, direct or indirect manipulations of BDNF levels or TrkB receptor activity are promising strategies to enhance the effect of fear extinction and less likely to diminish the effect of fear acquisition through conditioning. For its effects over extinction, the impact of manipulations of BDNF levels is highly related to the context in which such manipulations occur. Therefore, future trials will probably be directed at the investigation of methods that may enhance psychotherapy techniques that encompass exposure.

\section{INDIVIDUAL CONTRIBUTIONS}

Karina Soares de Oliveira - Performed the research and article compilation for this review and wrote the manuscript in its current format.

Juliana Belo Diniz - Provided the original idea that led to this review, wrote most of the content related to the relationship between anxiety and experimental manipulations of fear and reviewed the last version of this manuscript. 
Ana Gabriela Hounie and Carolina Cappi - Provided background in genetics and helped to interpret the findings from basic research regarding BDNF.

\section{CONFLICTS OF INTEREST}

The authors report no conflicts of interest. The authors alone are responsible for the content and writing of the article.

\section{ACKNOWLEDGEMENTS}

Karina Soares de Oliveira, Carolina Cappi and Juliana Belo Diniz are supported by the São Paulo Research Foundation (Fapesp, Grant no. 2012/09648-0, 2011/00968-0 and 2011/21357-9).

\section{REFERENCES}

1. Kessler RC, Chiu WT, Demler O, Merikangas KR, Walters EE. Prevalence, severity, and comorbidity of 12-month DSM-IV disorders in the National Comorbidity Survey Replication. Arch Gen Psychiatry. 2005;62:617-27.

2. Saarni SI, Suvisaari J, Sintonen H, Pirkola S, Koskinen S, Aromaa A, et al. Impact of psychiatric disorders on health-related quality of life: general population survey. $\mathrm{Br} J$ Psychiatry. 2007;190:326-32.

3. Ravindran LN, Stein MB. The pharmacologic treatment of anxiety disorders: a review of progress. J Clin Psychiatry. 2010;71:839-54.

4. Wittchen HU, Fehm L. Epidemiology and natural course of social fears and social phobia. Acta Psychiatr Scand Suppl. 2003:4-18.

5. Thuile J, Even C, Rouillon F. Long-term outcome of anxiety disorders: a review of doubleblind studies. Curr Opin Psychiatry. 2009;22:84-9.

6. Pollack MH, Otto MW, Roy-Byrne PP, Coplan JD, Rothbaum BO, Simon NM, et al. Novel treatment approaches for refractory anxiety disorders. Depress Anxiety. 2008;25:467-76.

7. Sylvers $P$, Lilienfeld SO, LaPrairie JL. Differences between trait fear and trait anxiety: implications for psychopathology. Clin Psychol Rev. 2011;31:122-37.

8. Grillon C. Models and mechanisms of anxiety: evidence from startle studies. Psychopharmacology (Berl). 2008;199:421-37.

9. Corcoran KA, Quirk GJ. Activity in prelimbic cortex is necessary for the expression of learned, but not innate, fears. J Neurosci. 2007;27:840-4.

10. Lissek S, Powers AS, McClure EB, Phelps EA, Woldehawariat G, Grillon C, et al. Classical fear conditioning in the anxiety disorders: a meta-analysis. Behav Res Ther. 2005;43:1391-424.

11. Milad MR, Orr SP, Pitman RK, Rauch SL. Context modulation of memory for fear extinction in humans. Psychophysiology. 2005;42:456-64.

12. Hembree EA, Riggs DS, Kozak MJ, Franklin ME, Foa EB. Long-term efficacy of exposure and ritual prevention therapy and serotonergic medications for obsessive-compulsive disorder. CNS Spectr. 2003;8:363-71, 81.

13. Foa EB, Liebowitz MR, Kozak MJ, Davies S, Campeas R, Franklin ME, et al. Randomized, placebo-controlled trial of exposure and ritual prevention, clomipramine, and their combination in the treatment of obsessive-compulsive disorder. Am J Psychiatry. 2005;162:151-61.

14. Bandelow B, Zohar J, Hollander E, Kasper S, Möller HJ, World Federation of Societies of Biological Psychiatry Task Force on Treatment Guidelines for Anxiety Os-CaPSD. World Federation of Societies of Biological Psychiatry (WFSBP) guidelines for the pharmacological treatment of anxiety, obsessive-compulsive and posttraumatic stress disorders. World J Biol Psychiatry. 2002;3:171-99.
15. Powers MB, Halpern JM, Ferenschak MP, Gillihan SJ, Foa EB. A meta-analytic review of prolonged exposure for posttraumatic stress disorder. Clin Psychol Rev. 2010;30:635-41.

16. Milad MR, Quirk GJ, Pitman RK, Orr SP, Fischl B, Rauch SL. A role for the human dorsal anterior cingulate cortex in fear expression. Biol Psychiatry. 2007;62:1191-4.

17. Rogan MT, Stäubli UV, LeDoux JE. Fear conditioning induces associative long-term potentiation in the amygdala. Nature. 1997;390:604-7.

18. Park H, Poo MM. Neurotrophin regulation of neural circuit development and function. Nat Rev Neurosci. 2013;14:7-23.

19. Lu B, Martinowich K. Cell biology of BDNF and its relevance to schizophrenia. Novartis Found Symp. 2008;289:119-29; discussion 29-35, 93-5.

20. Waterhouse $E G, X u B$. New insights into the role of brain-derived neurotrophic factor in synaptic plasticity. Mol Cell Neurosci. 2009;42:81-9.

21. Gupta VK, You Y, Gupta VB, Klistorner A, Graham SL. TrkB receptor signalling: implications in neurodegenerative, psychiatric and proliferative disorders. Int J Mol Sci. 2013;14:10122-42.

22. Rattiner LM, Davis M, Ressler KJ. Brain-derived neurotrophic factor in amygdaladependent learning. Neuroscientist. 2005;11:323-33.

23. Yamada K, Nabeshima T. Brain-derived neurotrophic factor/TrkB signaling in memory processes. J Pharmacol Sci. 2003;91:267-70.

24. Tyler WJ, Alonso M, Bramham CR, Pozzo-Miller LD. From acquisition to consolidation: on the role of brain-derived neurotrophic factor signaling in hippocampal-dependent learning. Learn Mem. 2002;9:224-37.

25. Liu IY, Lyons WE, Mamounas LA, Thompson RF. Brain-derived neurotrophic factor plays a critical role in contextual fear conditioning. J Neurosci. 2004;24:7958-63.

26. Heldt SA, Stanek L, Chhatwal JP, Ressler KJ. Hippocampus-specific deletion of BDNF in adult mice impairs spatial memory and extinction of aversive memories. Mol Psychiatry. 2007:12:656-70.

27. Sakata K, Martinowich K, Woo NH, Schloesser RJ, Jimenez DV, Ji Y, et al. Role of activitydependent BDNF expression in hippocampal-prefrontal cortical regulation of behavioral perseverance. Proc Natl Acad Sci U S A. 2013;110:15103-8.

28. Chhatwal JP, Stanek-Rattiner L, Davis M, Ressler KJ. Amygdala BDNF signaling is required for consolidation but not encoding of extinction. Nat Neurosci. 2006;9:870-2.

29. Rattiner LM, Davis M, French CT, Ressler KJ. Brain-derived neurotrophic factor and tyrosine kinase receptor B involvement in amygdala-dependent fear conditioning. J Neurosci. 2004:24:4796-806.

30. OuLC, Gean PW. Regulation of amygdala-dependentlearning by brain-derived neurotrophic factor is mediated by extracellular signal-regulated kinase and phosphatidylinositol-3kinase. Neuropsychopharmacology. 2006;31:287-96.

31. Milad MR, Rauch SL, Pitman RK, Quirk GJ. Fear extinction in rats: implications for human brain imaging and anxiety disorders. Biol Psychol. 2006;73:61-71.

32. Milad MR, Wright Cl, Orr SP, Pitman RK, Quirk GJ, Rauch SL. Recall of fear extinction in humans activates the ventromedial prefrontal cortex and hippocampus in concert. Biol Psychiatry. 2007;62:446-54.

33. Rattiner $L M$, Davis $M$, Ressler KJ. Differential regulation of brain-derived neurotrophic factor transcripts during the consolidation of fear learning. Learn Mem. 2004;11:727-31.

34. Barnes $P$, Thomas KL. Proteolysis of proBDNF is a key regulator in the formation of memory. PLoS One. 2008;3:e3248.

35. McDowell KA, Hutchinson AN, Wong-Goodrich SJ, Presby MM, Su D, Rodriguiz RM, et al. Reduced cortical BDNF expression and aberrant memory in Carf knock-out mice. J Neurosci. 2010;30:7453-65.

36. Preethi J, Singh HK, Venkataraman JS, Rajan KE. Standardised extract of Bacopa monniera (CDRI-08) improves contextual fear memory by differentially regulating the activity of histone acetylation and protein phosphatases (PP1a, PP2A) in hippocampus. Cell Mol Neurobiol. 2014;34:577-89.

37. Bredy TW, Wu H, Crego C, Zellhoefer J, Sun YE, Barad M. Histone modifications around individual BDNF gene promoters in prefrontal cortex are associated with extinction of conditioned fear. Learn Mem. 2007;14:268-76.

38. Lubin FD, Roth TL, Sweatt JD. Epigenetic regulation of BDNF gene transcription in the consolidation of fear memory. J Neurosci. 2008;28:10576-86. 
39. Sui $L$, Wang $Y$, Ju LH, Chen $M$. Epigenetic regulation of reelin and brain-derived neurotrophic factor genes in long-term potentiation in rat medial prefrontal cortex. Neurobiol Learn Mem. 2012;97:425-40

40. Rostami E, Krueger F, Zoubak S, Dal Monte 0, Raymont V, Pardini M, et al. BDNF polymorphism predicts general intelligence after penetrating traumatic brain injury. PLOS One. 2011;6:e27389.

41. Okada T, Hashimoto R, Numakawa T, lijima Y, Kosuga A, Tatsumi M, et al. A complex polymorphic region in the brain-derived neurotrophic factor (BDNF) gene confers susceptibility to bipolar disorder and affects transcriptional activity. Mol Psychiatry. 2006;11:695-703.

42. Vincze I, Perroud N, Buresi C, Baud P, Bellivier F, Etain B, et al. Association between brainderived neurotrophic factor gene and a severe form of bipolar disorder, but no interaction with the serotonin transporter gene. Bipolar Disord. 2008;10:580-7.

43. Hajcak G, Castille C, Olvet DM, Dunning JP, Roohi J, Hatchwell E. Genetic variation in brainderived neurotrophic factor and human fear conditioning. Genes Brain Behav. 2009;8:80-5.

44. Lonsdorf TB, Weike Al, Golkar A, Schalling M, Hamm A0, Ohman A. Amygdala-dependent fear conditioning in humans is modulated by the BDNFval66met polymorphism. Behav Neurosci. 2010;124:9-15.

45. LonsdorfTB, Golkar A, Lindström KM, Haaker J, Öhman A, Schalling M, et al. BDNFval66met affects neural activation pattern during fear conditioning and $24 \mathrm{~h}$ delayed fear recall. Soc Cogn Affect Neurosci. 2015;10:664-71.

46. Mühlberger A, Andreatta M, Ewald H, Glotzbach-Schoon E, Tröger C, Baumann C, et al. The BDNF Val66Met polymorphism modulates the generalization of cued fear responses to a novel context. Neuropsychopharmacology. 2014;39:1187-95.

47. Soliman F, Glatt CE, Bath KG, Levita L, Jones RM, Pattwell SS, et al. A genetic variant BDNF polymorphism alters extinction learning in both mouse and human. Science. 2010;327:863-6.

48. Zeng Y, Liu Y, Wu M, Liu J, Hu Q. Activation of TrkB by 7,8-dihydroxyflavone prevents fear memory defects and facilitates amygdalar synaptic plasticity in aging. J Alzheimers Dis. 2012:31:765-78

49. Andero R, Heldt SA, Ye K, Liu X, Armario A, Ressler KJ. Effect of 7,8-dihydroxyflavone, a small-molecule TrkB agonist, on emotional learning. Am J Psychiatry. 2011;168:163-72.

50. A controlled trial of recombinant methionyl human BDNF in ALS: The BDNF Study Group (Phase III). Neurology. 1999;52:1427-33.

51. Song Z, Chen Q, Ding Q, Zheng F, Li C, Xu L, et al. Function of CaZ2+-/calmodulin-dependent protein kinase IV in Ca2+-stimulated neuronal signaling and behavior. Sci China Life Sci. 2015;58:6-13.

52. Gururajan A, Hill RA, van den Buuse M. Brain-derived neurotrophic factor heterozygous mutant rats show selective cognitive changes and vulnerability to chronic corticosterone treatment. Neuroscience. 2015;284:297-310.

53. Wang J, Freire D, Knable L, Zhao W, Gong B, Mazzola P, et al. Childhood and adolescent obesity and long-term cognitive consequences during aging. J Comp Neurol. 2015:523:757-68

54. Gibbons TE, Pence BD, Petr G, Ossyra JM, Mach HC, Bhattacharya TK, et al. Voluntary wheel running, but not a diet containing (-)-epigallocatechin-3-gallate and $\beta$-alanine, improves learning, memory and hippocampal neurogenesis in aged mice. Behav Brain Res. 2014;272:131-40.

55. Dincheva I, Pattwell SS, Tessarollo L, Bath KG, Lee FS. BDNF modulates contextual fear learning during adolescence. Dev Neurosci. 2014;36:269-76.

56. Chen C, Ji M, Xu Q, Zhang Y, Sun Q, Liu J, et al. Sevoflurane attenuates stress-enhanced fear learning by regulating hippocampal BDNF expression and Akt/GSK-3 $\beta$ signaling pathway in a rat model of post-traumatic stress disorder. J Anesth 2015;29:600-8.

57. Fan D, Li J, Zheng B, Hua L, Zuo Z. Enriched Environment Attenuates Surgery-Induced Impairment of Learning, Memory, and Neurogenesis Possibly by Preserving BDNF Expression. Mol Neurobiol. 2016;53:344-54.

58. Heldt SA, Zimmermann K, Parker K, Gaval M, Weinshenker D, Ressler KJ. BDNF deletion or TrkB impairment in amygdala inhibits both appetitive and aversive learning. J Neurosci. 2014;34:2444-50

59. Schulz-Klaus B, Lessmann $V$, Endres T. BDNF-dependent consolidation of fear memories in the perirhinal cortex. Front Behav Neurosci. 2013;7:205

60. Psotta L, Lessmann V, Endres T. Impaired fear extinction learning in adult heterozygous BDNF knock-out mice. Neurobiol Learn Mem. 2013;103:34-8.
61. Endres T, Lessmann V. Age-dependent deficits in fear learning in heterozygous BDNF knock-out mice. Learn Mem. 2012;19:561-70.

62. Choi DC, Gourley SL, Ressler KJ. Prelimbic BDNF and TrkB signaling regulates consolidation of both appetitive and aversive emotional learning. Transl Psychiatry. 2012;2:e205.

63. Meis S, Endres T, Lessmann V. Postsynaptic BDNF signalling regulates long-term potentiation at thalamo-amygdala afferents. J Physiol. 2012;590:193-208.

64. Uutela M, Lindholm J, Louhivuori V, Wei H, Louhivuori LM, Pertovaara A, et al. Reduction of BDNF expression in Fmr1 knockout mice worsens cognitive deficits but improves hyperactivity and sensorimotor deficits. Genes Brain Behav. 2012;11:513-23.

65. Kleschevnikov AM, Belichenko PV, Faizi M, Jacobs LF, Htun K, Shamloo M, et al. Deficits in cognition and synaptic plasticity in a mouse model of Down syndrome ameliorated by GABAB receptor antagonists. J Neurosci. 2012;32:9217-27.

66. Oyagi A, Moriguchi S, Nitta A, Murata K, Oida Y, Tsuruma K, et al. Heparin-binding EGFlike growth factor is required for synaptic plasticity and memory formation. Brain Res. 2011;1419:97-104.

67. Kimura R, Devi L, Ohno M. Partial reduction of BACE1 improves synaptic plasticity, recent and remote memories in Alzheimer's disease transgenic mice. J Neurochem. 2010;113:248-61.

68. Jin CH, Shin EJ, Park JB, Jang CG, Li Z, Kim MS, et al. Fustin flavonoid attenuates betaamyloid (1-42)-induced learning impairment. J Neurosci Res. 2009;87:3658-70.

69. Rossato JI, Bevilaqua LR, Izquierdo I, Medina JH, Cammarota M. Dopamine controls persistence of long-term memory storage. Science. 2009;325:1017-20.

70. Woolley ML, Waters KA, Gartlon JE, Lacroix LP, Jennings C, Shaughnessy F, et al Evaluation of the pro-cognitive effects of the AMPA receptor positive modulator, 5-(1-piperidinylcarbonyl)-2,1,3-benzoxadiazole (CX691), in the rat. Psychopharmacology (Berl). 2009;202:343-54.

71. Bilbo SD, Barrientos RM, Eads AS, Northcutt A, Watkins LR, Rudy JW, et al. Early-life infection leads to altered BDNF and IL-1beta mRNA expression in rat hippocampus following learning in adulthood. Brain Behav Immun. 2008;22:451-5.

72. Greenwood BN, Strong PV, Foley TE, Fleshner M. A behavioral analysis of the impact of voluntary physical activity on hippocampus-dependent contextual conditioning. Hippocampus. 2009;19:988-1001.

73. Gourley SL, Kedves AT, Olausson P, Taylor JR. A history of corticosterone exposure regulates fear extinction and cortical NR2B, GluR2/3, and BDNF. Neuropsychopharmacology. 2009;34:707-16.

74. Liu YF, Chen HI, Yu L, Kuo YM, Wu FS, Chuang Jl, et al. Upregulation of hippocampal TrkB and synaptotagmin is involved in treadmill exercise-enhanced aversive memory in mice. Neurobiol Learn Mem. 2008;90:81-9.

75. Bozdagi 0, Rich E, Tronel S, Sadahiro M, Patterson K, Shapiro ML, et al. The neurotrophininducible gene Vgf regulates hippocampal function and behavior through a brain-derived neurotrophic factor-dependent mechanism. J Neurosci. 2008;28:9857-69.

76. Chen J, Kitanishi T, Ikeda T, Matsuki N, Yamada MK. Contextual learning induces an increase in the number of hippocampal CA1 neurons expressing high levels of BDNF. Neurobiol Learn Mem. 2007:88:409-15.

77. Ou LC, Gean PW. Transcriptional regulation of brain-derived neurotrophic factor in the amygdala during consolidation of fear memory. Mol Pharmacol. 2007;72:350-8.

78. Jones SV, Stanek-Rattiner L, Davis M, Ressler KJ. Differential regional expression of brainderived neurotrophic factor following olfactory fear learning. Learn Mem. 2007;14:816-20.

79. Moretti P, Levenson JM, Battaglia F, Atkinson R, Teague R, Antalffy B, et al. Learning and memory and synaptic plasticity are impaired in a mouse model of Rett syndrome. J Neurosci. 2006;26:319-27.

80. Aguilar-Valles A, Sánchez E, de Gortari P, Balderas I, Ramírez-Amaya V, Bermúdez-Ratton $F$, et al. Analysis of the stress response in rats trained in the water-maze: differential expression of corticotropin-releasing hormone, CRH-R1, glucocorticoid receptors and brain-derived neurotrophic factor in limbic regions. Neuroendocrinology. 2005;82:306-19.

81. Alonso M, Bekinschtein P, Cammarota M, Vianna MR, Izquierdo I, Medina JH. Endogenous BDNF is required for long-term memory formation in the rat parietal cortex. Learn Mem. 2005:12:504-10.

82. Chourbaji S, Hellweg R, Brandis D, Zörner B, Zacher C, Lang UE, et al. Mice with reduced brain-derived neurotrophic factor expression show decreased choline acetyltransferase activity, but regular brain monoamine levels and unaltered emotional behavior. Brain Res Mol Brain Res. 2004;121:28-36 
83. Barrientos RM, Sprunger DB, Campeau S, Watkins LR, Rudy JW, Maier SF. BDNF mRNA expression in rat hippocampus following contextual learning is blocked by intrahippocampal IL-1beta administration. J Neuroimmunol. 2004;155:119-26.

84. Barrientos RM, Sprunger DB, Campeau S, Higgins EA, Watkins LR, Rudy JW, et al. Brainderived neurotrophic factor mRNA downregulation produced by social isolation is blocked by intrahippocampal interleukin-1 receptor antagonist. Neuroscience. 2003;121:847-53.

85. Gorski JA, Balogh SA, Wehner JM, Jones KR. Learning deficits in forebrain-restricted brainderived neurotrophic factor mutant mice. Neuroscience. 2003;121:341-54.

86. Andero R, Choi DC, Ressler KJ. BDNF-TrkB receptor regulation of distributed adult neural plasticity, memory formation, and psychiatric disorders. Prog Mol Biol Transl Sci. 2014;122:169-92.

87. Felmingham KL, Dobson-Stone C, Schofield PR, Quirk GJ, Bryant RA. The brain-derived neurotrophic factor Val66Met polymorphism predicts response to exposure therapy in posttraumatic stress disorder. Biol Psychiatry. 2013;73:1059-63.

88. Aguiar AS, Speck AE, Prediger RD, Kapczinski F, Pinho RA. Downhill training upregulates mice hippocampal and striatal brain-derived neurotrophic factor levels. J Neural Transm. 2008;115:1251-5.

89. Greenwood BN, Strong PV, Foley TE, Fleshner M. A behavioral analysis of the impact of voluntary physical activity on hippocampus-dependent contextual conditioning. Hippocampus. 2009;19:988-1001.

90. Powers MB, Medina JL, Burns S, Kauffman BY, Monfils M, Asmundson GJ, et al. Exercise Augmentation of Exposure Therapy for PTSD: Rationale and Pilot Efficacy Data. Cogn Behav Ther. 2015;44:314-27.
91. Rantamäki T, Vesa L, Antila H, Di Lieto A, Tammela P, Schmitt A, et al. Antidepressant drugs transactivate TrkB neurotrophin receptors in the adult rodent brain independently of BDNF and monoamine transporter blockade. PLoS One. 2011;6:e20567.

92. Rantamäki T, Yalcin I. Antidepressant drug action - From rapid changes on network function to network rewiring. Prog Neuropsychopharmacol Biol Psychiatry. 2016;64:285-92.

93. Karpova NN, Pickenhagen A, Lindholm J, Tiraboschi E, Kulesskaya N, Agústsdóttir A, et al. Fear erasure in mice requires synergy between antidepressant drugs and extinction training. Science. 2011;334:1731-4.

94. Deschaux 0, Spennato G, Moreau JL, Garcia R. Chronic treatment with fluoxetine prevents the return of extinguished auditory-cued conditioned fear. Psychopharmacology (Berl). 2011;215:231-7.

95. Yang CH, Shi HS, Zhu WL, Wu P, Sun LL, Si JJ, et al. Venlafaxine facilitates between-session extinction and prevents reinstatement of auditory-cue conditioned fear. Behav Brain Res. 2012;230:268-73.

96. Burghardt NS, Sigurdsson T, Gorman JM, McEwen BS, LeDoux JE. Chronic antidepressant treatment impairs the acquisition of fear extinction. Biol Psychiatry. 2013;73:1078-86.

97. Lebrón-Milad K, Tsareva A, Ahmed N, Milad MR. Sex differences and estrous cycle in female rats interact with the effects of fluoxetine treatment on fear extinction. Behav Brain Res. 2013;253:217-22.

98. Bui E, Orr SP, Jacoby RJ, Keshaviah A, LeBlanc NJ, Milad MR, et al. Two weeks of pretreatment with escitalopram facilitates extinction learning in healthy individuals. Hum Psychopharmacol. 2013;28:447-56. 